\title{
ATIVIDADE FINANCEIRA E MOEDA: ANÁLISE DA EXPERIÊNCIA DO CONJUNTO PALMEIRAS EM FORTALEZA-CE *
}

\author{
Uinie Caminha e Monique Figueiredo
}

FINANCIAL ACTIVITY AND CURRENCY: ANALISYS OF THE EXPERIENCE OF "CONJUNTO PALMEIRAS" IN FORTALEZA-CE

\section{RESUMO}

O Conselho Monetário Nacional (CMN) REgula o acesso e FISCALIZA AS ATIVIDADES DAS INSTITUIC̄õES FINANCEIRAS QUE PARTICIPAM do Sistema Financeiro NaCIONAL (SFN). EsSE CONTROLE DO SFN É ESSENCIAL, POIS O SISTEMA FINANCEIRO É SUSCETIVEL A CRISES DE CONFIANÇA E SAQUES EM MASSA, E AINDA INSTRUMENTALIZA POLÍTICAS MONETÁRIAS COM O INTUITO DE CONTROLAR ÍNDICES INFLACIONÁRIOS. UM DOS MECANISMOS DE CONTROLE INFLACIONÁRIO É A EMISSÃO DE PAPEL MOEDA, SENDO QUE, DE ACORDO COM A CONSTITUIÇÃo FEDERAL DE 1988, A INCUMBÊNCIA DE EMITIR, CONTROLAR E REGULAMENTAR A MOEDA OFICIAL É EXCLUSIVA DA UNIÃO. NO ENTANTO, VÊM CRESCENDO EXPERIÊNCIAS DE ECONOMIA SOLIDÁRIA, NA QUAL SE ENCONTRAM REDES DE PRODUÇÃO E CONSUMO, ALÉM DE MEIOS ALTERNATIVOS DE PAGAMENTO. O OBJETIVO DESTE ARTIGO É ANALISAR A EXPERIÊNCIA NO BAIRRO CONJUNTO PALMEIRAS, NA cidade de Fortaleza, Ceará, sua estrutura, seus projetos, E ESPECIALMENTE A EMISSÃO DA MOEDA SOCIAL DO BAIRRO (PALMA, P\$), BEM COMO UM PROJETO DE MICROCRÉDITO E FINANCIAMENTO PARA OS MORADORES LOCAIS, VERIFICANDO SE HÁ POSSIBILIDADES DE INTEGRAR TAIS PRÁTICAS AO SFN, UMA VEZ QUE, ATÉ ENTÃO, SÃO ATIVIDADES QUE DEVERIAM SER EXERCIDAS PRIVATIVAMENTE POR INSTITUIÇÕES FINANCEIRAS.

\section{PALAVRAS-CHAVE}

Sistema Financeiro Nacional, Economia Solidária, Moeda, Meios de pagamento, Conjunto Palmeiras

\begin{abstract}
The National Monetary Council (CMN) Regulates and CONTROLS THE ACTIVITIES OF FINANCIAL INSTITUTIONS WHICH PARTICIPATE IN NATIONAL FINANCIAL SyStem (SFN). SUCH CONTROL IS CRITICAL SINCE THE FINANCIAL SYSTEM IF SUCEPTIBLE TO CONFINDENCE CRISIS AND MASSIVE WITHDRAWLS, AND YET ENGAGES MONETARY POLICIES AIMING AT CONTROLING INFLATION RATES. ONE OF THE INSTRUMENTS TO CONTROL INFLATION IS THE ISSUANCE OF CURRENCY SINCE, ACCORDING TO FEDERAL CONTITUITION OF 1988, THE INCUMBECY OF ISSUING, CONTROLLING AND REGULATION THE OFFICAL CURRENCY IF EXCLUSIVE OF THE UNION. HOWEVER, SEVERAL EXPERIENCES OF "SOLIDARY ECONOMY" IN WHICH PRODUCTION AND CONSUMPTION NETWORKS ARE FOUND, IN ADDITION TO ALTERNATIVE MEANS OF PAYMENT. THE SCOPE OF THIS ARTICLE IS TO ANALYSE THE EXPERIENCE OF "Conjunto Palmeiras" in Fortaleza, Ceará, its STRUCTURE, ITS PROJECTS AND SPECIALLY THE ISSUANCE OF THE SOCIAL CURRENCY OF THE NEIGHBORHOOD (PALMA, P\$), AS WELL AS A MICROCREDIT AND FUNDING PROJECT FOR LOCAL RESIDENTS, VERIFYING IF SUCH EXPERIENCE COMPLIES WITH THE SFN RULES SINCE SUCH ACTIVITIES ARE ONLY ALLOWED TO FINANCIAL INSTITUTIONS.
\end{abstract}

\section{KEYWORDS}

National Financial SYStem, "SOlidary ECONOMY", Currency, means of payment, "Conjunto Palmeiras"

\section{INTRODUÇÃO}

O Conselho Monetário Nacional (CMN) regula o acesso de instituições, de natureza pública ou privada, ao Sistema Financeiro Nacional (SFN), bem como fiscaliza e 
legisla sobre suas atividades, submetendo-as às finalidades previstas pelo art. 192 da Constituição Federal, qual seja: "promover o desenvolvimento equilibrado do país e servir aos interesses da coletividade, garantindo o funcionamento do sistema e principalmente a implementação das políticas econômica e monetária do país".

Com a fundação do Banco do Brasil, em 1808, iniciou-se a história da disciplina monetária no país. A motivação preponderante para a criação do Banco do Brasil foi o Estado necessitar de um ente que financiasse, através da emissão de moeda, a máquina pública. O início do sistema bancário no Brasil foi marcado pela ausência de delimitações entre as atribuições e funções do Banco do Brasil, emissor da moeda de curso forçado, e o Tesouro. Consequentemente, as políticas monetárias aplicadas não preveniram os consideráveis índices de inflação, desvalorização da moeda e desorganizaram o sistema monetário.

Esse quadro de economia instável fora, todavia, encontrado não só no Império, mas também na República. A desordem orçamentária e a desregrada emissão de moeda desequilibraram a economia, a ponto de ser imprescritível a urgente instituição de uma autoridade monetária, com poderes exclusivos para orientar, controlar e regularizar a circulação da moeda. Diversas iniciativas precederam a criação do Banco Central, em 1964. Porém, a falta de autonomia e independência dos órgãos aos quais se atribuía a função de guardião da moeda fez com que o objetivo de estabilizar o sistema financeiro fosse adiado.

Daí surgiu o Banco Central do Brasil, em 1964, pela Lei 4.595 de 31 de dezembro, a qual reformulou o Sistema Financeiro Nacional. Atualmente, contempla a Constituição Federal, em seu artigo 164, caput, que a prerrogativa de emissão de moeda, pertencente à União, é exercida pelo Banco Central do Brasil em caráter de exclusividade.

Todavia, no Brasil (também em outros países) tem-se fortalecido a chamada economia solidária ou socioeconomia solidária, que é uma forma paralela de produzir, comercializar e ofertar crédito em desenvolvimento. Não pretende o presente artigo debruçar sobre essa economia dita solidária, em si, mas a possível presença, nesse tipo de economia, da emissão e circulação de uma moeda local, chamada de social.

Como objeto de estudo foi escolhido o Conjunto Palmeiras, bairro periférico situado na cidade de Fortaleza, Ceará, onde há a emissão e circulação de uma moeda social denominada de palma (P\$).

Sabe-se que o Sistema Financeiro Nacional, atualmente, cumpre funções que vão além do tradicional binômio captação de recursos - oferta de crédito. Com efeito, as instituições que o compõe prestam serviços, podendo ser considerados indispensáveis ao exercício de uma série de atividades ligadas a direitos básicos de cidadania. A exclusão do sistema bancário pode comprometer o bem-estar e integração desses indivíduos com a sociedade. 
Alguns mecanismos vêm sendo criados com o objetivo de oferecer a uma parcela da população serviços financeiros, sejam por meios oficiais - como a criação do Banco Popular e dos Correspondentes Bancários -, ou não oficiais - iniciativas das próprias comunidades que possuem dificuldades em obter acesso ao Sistema Financeiro oficial. Destaca-se, dentre elas, a experiência do Conjunto Palmeiras. Lá, por iniciativa da Associação de Moradores do Conjunto Palmeiras (Amoconp), foi fundado, em 1998, o chamado Banco Palmas. Não se trata de uma instituição financeira no estrito sentido da palavra, mas de uma entidade constituída com a finalidade de impulsionar a economia local através do método de fomento (Movimento Monetário Mosaico, MoMoMo), promover a inclusão social, o bem-estar e oferecer alternativas para os problemas socioeconômicos.

Para viabilizar essa iniciativa foram criadas linhas de financiamento e concessão de crédito para os moradores do bairro, como, por exemplo, o "Palmacard", um cartão de crédito local. Além disso, outra medida adotada foi a criação da moeda social palma (P\$), com uso local, indexada e lastreada pelo real (R\$).

Diante dessas considerações, buscou-se desenvolver uma pesquisa para responder aos seguintes questionamentos: há guarida no nosso ordenamento jurídico, notadamente no texto constitucional e na legislação infraconstitucional, que torne legal a prática de emissão de moeda solidária? Estaria de acordo com o conceito de moeda solidária a experiência vivenciada no Conjunto Palmeiras? A experiência de emissão da moeda palma fere o Sistema Financeiro Nacional?

Neste artigo, tem-se como objetivo geral analisar o fato concreto sob o aspecto da legislação vigente, questionando a compatibilidade da experiência e o Sistema Financeiro Nacional e, como objetivos específicos: analisar o surgimento da moeda; analisar o Sistema Financeiro Nacional, sua história, composição e estrutura; observar a compatibilidade da moeda social com os preceitos constitucionais relativos ao Sistema Financeiro Nacional.

Quanto aos aspectos metodológicos usados foi realizado através de um estudo descritivo-analítico, desenvolvido através de análise bibliográfica aprofundada, baseada em trabalhos publicados sob a forma de livros, revistas, artigos, dissertações, teses, publicações especializadas, imprensa escrita e dados oficiais publicados na internet que abordassem direta ou indiretamente o tema em análise, e de forma específica em relação ao Sistema Financeiro Nacional, bem como sobre economia solidária. Além disso, fizemos uma pesquisa de campo através de coleta de dados, observação direta no banco local, entrevista estruturada com os funcionários e, por fim, aplicação de questionários de forma presencial a moradores do bairro.

No que tange à tipologia da pesquisa, esta é, segundo a utilização dos resultados, pura, visto ter sido realizada apenas com o intuito de ampliar os conhecimentos. Segundo a abordagem, é qualitativa, com a apreciação da realidade no que concerne ao tema no ordenamento jurídico pátrio. Quanto aos objetivos, a pesquisa é descritiva, já 
que busca descrever, explicar, classificar e esclarecer o problema apresentado; e exploratória, uma vez que procura aprimorar ideias, buscando maiores informações sobre a temática em foco.

Para fins didáticos, o presente artigo divide-se em quatro seções, distribuídas na da seguinte forma:

A primeira seção aborda o surgimento da moeda como meio de trocas, sua evolução, características e importância. Na segunda seção, apresentamos uma análise do Sistema Financeiro Nacional (SFN) - este como fruto de uma evolução histórica, na qual tem, como principal ator, a eleição de um único instrumento efetivo para as trocas, a moeda - e demonstramos a composição do SFN, seus benefícios e possíveis ações contra a ordem econômica.

A terceira seção é dedicada exclusivamente à economia solidária, suas características e práticas no Brasil e no mundo, bem como a exploração do conceito de moeda social, suas limitações e práticas.

$\mathrm{Na}$ última seção, trataremos do caso concreto (objeto de análise), sua adequação ao que se denomina de economia solidária e moeda social, e, consequentemente, a compatibilidade ao Sistema Financeiro Nacional.

Ao final, expomos as derradeiras considerações de nosso estudo, refletindo sobre a importância de uma regulação sobre o tema em análise e a fiscalização pelo Banco Central.

\section{MOEDA}

Diversas correntes teóricas se propõem a justificar se o surgimento da moeda ${ }^{1}$ resultou de um processo espontâneo ou por criação do Estado.

Esse debate teórico demonstra a importância do papel da moeda na evoluída sociedade, pois sendo ela o instrumento basilar do mercado, da globalização e do avanço tecnológico, não seria possível imaginar a vida econômica da sociedade sem a sua existência.

Por isso, constantemente deverá ser explorado (e reafirmado) o seu conceito e importância, uma vez que novos comportamentos econômicos surgem e nem sempre estão em conformidade com a realidade jurídica existente.

\section{I ORIGEM E CONCEITO}

Em um retrospecto histórico, observa-se que o homem primitivo buscava saciar suas necessidades imediatamente, inexistindo a preocupação de acumular os bens ou mesmo atribuir a eles valores determinados.

Com o agrupamento de indivíduos, ou seja, com o início da vida em sociedade, surge a necessidade de alocar bens. Com efeito, nos primórdios da sociedade, a alocação de bens ocorria naturalmente, seja porque já era percebida a escassez dos bens 
naturais, ou porque trocar os excedentes era mais prático do que partir para a busca do que estava faltando.

Essa simples permuta satisfazia, de forma direta, uma necessidade imediata. Nesse fato social, contudo, existia um obstáculo: a dificuldade de coincidir o bem abundante de um com a escassez do outro.

Em uma pequena sociedade, essa dificuldade era provavelmente superada, mas com o crescimento e natural evolução das relações através do contato com outras sociedades, a solução para viabilizar o câmbio seria a aceitação de determinado bem, o qual, no momento, não necessitava, mas o qual, posteriormente, poderia ser trocado facilmente por ser objeto de comum apreciação.

Com isso, um bem estimado/ útil por determinada sociedade era eleito como dinamizador das permutas, mas ele variava no tempo e entre os grandes grupos sociais, dependendo do que cada cultura apreciava como bem útil.

Outro ponto há de ser observado nessa dinâmica social. Para atingir a efetivação das trocas, os membros não desejavam apenas a autossatisfação (o exclusivo interesse pessoal), eles buscavam, também, satisfazer a necessidade do outro a fim de possibilitar a permuta.

Como medir o valor dos bens? Não existia a padronização dos valores, mas como o bem Sal era facilmente negociado, a relação se perfazia. Diante desse contexto socioeconômico, surge, então, a moeda, que poderia ser qualquer objeto estimado por determinado grupo social, e por isso era escolhido para integrar nas/ as relações, ${ }^{2}$ nas quais se encontra presente a urgência de satisfação própria e alheia, como unidade monetária.

A moeda é um ativo padronizado como meio liberatório, é um "mecanismo 'ideal' que preconiza a padronização dos pagamentos em termos de uma dada unidade" (Castro, 2005). "Ideal” porque lhe é abstraída qualquer relação com o material físico que a compõe, podendo ser expressa por qualquer meio/ bem, o qual será padronizador de pagamentos e não de trocas.

Há duas teorias distintas sobre o que vem a ser moeda e suas características: a metalista e a nominalista. O conceito metalista, ${ }^{3}$ conhecido também como bulionismo, atribui que o índice de riqueza ou poder de uma nação baseia-se na quantidade de metais preciosos possuidos. ${ }^{4}$

Com a evolução do sistema financeiro, a equivalência entre a moeda circulante com o metal ouro desfez-se aparentemente por completo, sem o sistema monetário deixar de funcionar. Atualmente, o sistema monetário não está intrinsecamente ligado com a sua reserva de ouro, portanto, percebe-se que a teoria metalista teve seu sentido e respaldo apenas no passado.

Em contraposição, encontra-se a teoria nominalista ${ }^{5}$ que dissemina a ideia que a moeda não é mercadoria nem mesmo tem em si um valor material. Seria, então, a moeda aceita pelo seu valor nominal (simbólico) nas relações de troca; nesse contexto, 
o material da moeda não constitui valor econômico, na verdade, é uma criação do Estado (instrumento financeiro) dotada de poder liberatório.

Diversos ramos do direito tratam do valor nominal da moeda. Para o Direito Civil, Empresarial e para a Economia, o valor nominal "é o valor que o poder estatal competente atribui à moeda nacional e que é inscrito em cada peça monetária” (Camargo, 2002). Já Latécio Jansen (2000) entende, com base no Direito Monetário, que essa expressão refere-se “ao princípio segundo o qual a moeda nacional (isto é, o valor nominal) é o fundamento de validade de todas as normas monetárias no ordenamento jurídico considerado”.

Discussões à parte, o importante é enfatizar que para a teoria nominalista, o valor da moeda não está correlacionado ao valor do material que a constitui. Logo, segundo essa teoria o metal ouro, engrandecido pelos metalistas, não possui o condão de embasar todo o sistema monetário; os nominalistas admitem o abandono do ouro como parâmetro na fixação do valor do dinheiro.

Para um dado objeto ser denominado de moeda, torna-se irrefutável observar se tal elemento é aceito por determinada coletividade e se desempenha as funções de instrumento de troca, meio de pagamento, reserva de valor e denominação comum de valores; não sendo cogente que tal elemento seja um metal precioso.

\section{I.2 MOEDA X DINHEIRO}

Em qualquer relação existe a necessidade de salvaguardas, as garantias entre as partes. Se hoje, em uma sociedade mais evoluída e institucionalizada, ainda existe essa preocupação com as garantias nas relações, bem mais forte era no início das relações econômicas.

Com efeito, a escolha de uma unidade monetária trouxe a devida dinâmica para as relações econômicas na sociedade. Todavia, para uma interação comercial maior, a moeda deveria ser aceita não apenas por um determinado grupo, mas por toda a sociedade de forma erga omnes. Para isso, deveria ser a moeda instituída por normas, pois, assim, seria a única na sociedade e apreciada de forma absoluta.

A dinâmica econômica da sociedade evoluiu a ponto de a unidade monetária precisar ser algo imposto pelo poder normativo. Surge então o dinheiro, como fruto de uma necessidade social, com reconhecimento político e juridicamente instituído (normas).

Pode-se deduzir a diferença entre a moeda (gênero) e o dinheiro (espécie): a primeira como qualquer bem eleito para viabilizar as permutas, e esse último como o bem eleito e instituído com força normativa por aquele que tem o poder vinculante de eleger a moeda oficial.

Sendo o dinheiro a moeda oficial por ação do Estado Soberano, ele desmonta na obrigatoriedade da aceitação por todos. Essa característica de meio de pagamento compulsório é denominada de curso legal da moeda. 
A moeda oficial tem outra característica, o chamado curso forçado, que é o regime monetário da inconversibilidade do papel-moeda; o curso forçado faz prevalecer a expressão nominal do instrumento monetário, impedindo, assim, a conversão em seu lastro.

Vale explanar os questionamentos sobre a origem do dinheiro: se foi natural/ espontâneo ou instituído por criação estatal.

Sobre a primeira hipótese, Menger afirma que o surgimento do dinheiro resultou de um processo natural e despretensioso na sociedade. O Estado entrou em cena após o surgimento das moedas cunhadas, como garantidor da pureza e do peso das pedras utilizadas para o cunho das moedas, bem como para coibir as possíveis falsificações:

A origem do dinheiro (que deve distinguir-se das moedas cunhadas) é, como temos visto, de todo natural e, por conseguinte, só em raros casos pode-se atribuir a influências legislativas. O dinheiro não é uma invenção estatal nem produto de um ato legislador. (...) O fato de que umas determinadas mercadorias alcancem a categoria de dinheiro surge espontaneamente das relações econômicas existentes, sem que sejam precisas medidas estatais. (...) De onde se depreende que os bens que alcançaram essa especial categoria de dinheiro tenham variado nos mesmos povos durante épocas distintas e também tenham sido diferentes, dentro de uma mesma época, entre diferentes povos. ${ }^{6}$

Knapp, por sua vez, defendia de forma contrária essa corrente teórica. Demonstra em sua obra ter o Estado aptidão para determinar o que é dinheiro, entretanto, não é considerado dinheiro a moeda por ele emitida, mas as que por ele são aceitas:

O que faz parte do sistema monetário do Estado e o que não faz? Não devemos tomar nossa definição muito estreita. O critério não poderia ser que a moeda é emitida pelo Estado, porque isso excluiria modalidades de moeda que são da mais alta importância: eu me refiro às notas bancárias: elas não são emitidas pelo Estado, mas fazem parte do sistema monetário. Nem pode a moeda de curso legal ser tomada como critério, porque em sistemas monetários há frequentes modalidades de dinheiro que não são de curso legal. (...) Ficamos mais perto dos fatos se tomamos como nosso critério que o dinheiro seja aceito nos pagamentos feitos aos guichês do Estado. Então todos os meios pelos quais um pagamento pode ser feito ao Estado fazem parte do sistema monetário. Nessa base não é a emissão, mas a aceitação, como a chamamos, que é decisiva. A aceitação estatal delimita o sistema monetário. Pela expressão "aceitação estatal" entenda-se somente a aceitação nos guichês de pagamento do Estado onde o Estado é o recebedor. ${ }^{7}$ 
Knapp entende que a moeda do Estado (dinheiro) é almejada por todos, e lembra que, em uma disputa judicial, o credor será ressarcido com a moeda aceita pelo Estado. ${ }^{8}$

Independente de o surgimento do dinheiro ter sido natural ou espontâneo, outra dificuldade precisaria ser superada na sociedade em desenvolvimento mesmo com a instituição da moeda oficial: as consequências maléficas geradas pela permissão de livre cunhagem da moeda.

Havia, até então, uma disponibilidade da moeda oficial no mercado, uma vez que, ao necessitá-la, o indivíduo poderia levar o metal para "bater moeda", de igual modo sucedia com os bancos, depositários de riquezas e livres autônomos emissores da moeda.

Essa prática culminou em uma economia insegura, cuja abundância ou escassez da moeda era impossível de mensurar por existir uma produção incalculável. Logo transpareceram divergências entre a liberdade "privada" da criação monetária e a urgência pelo monopólio estatal na emissão do dinheiro.

As experiências com a emissão privada da moeda mostram a ausência de garantias e a extrema insegurança nos sistemas, devido ao fato de o Estado não possuir o controle absoluto da emissão e da circulação da moeda. A proibição da emissão privada é o resultado da evolução satisfatória do dinheiro (moeda oficial) e da organização política, econômica e social.

\section{SISTEMA FINANCEIRO NACIONAL}

A abordagem teórico-conceitual da seção anterior sobre as peças fundamentais desse trabalho (dinheiro e moeda) se formou com o propósito de adentrar na definição, história e estrutura do Sistema Financeiro Nacional.

\section{I DA MOEDA AO SISTEMA FINANCEIRO}

A estrutura facilmente percebida e a razão de ser do que se denomina "sistema financeiro" desenvolveu-se (definindo competências, ramificações e normas) no transcorrer do tempo. Contudo, o apelo ao seu surgimento possui uma ligação intrínseca à anterior criação do seu substrato (moeda) e o papel que esse último assumiu na sociedade.

Como bem afirma Raphael Castro (2005), em tempos remotos (anteriores à instituição monetária), a figura dos bancos já era percebida, logicamente, despossuída da estrutura e infinitos serviços observados na atualidade.

Inexistindo a diversidade de formas de atuação dos bancos, restava-lhes, portanto, exercer o papel de guardião (local seguro) dos objetos considerados valiosos por aqueles que optavam por sua preservação. Com a instituição normativa do instrumento oficial liberatório (o dinheiro) houve um engrandecimento do papel dos bancos.

Cabe elucidar que a simples existência da presença estrutural dos bancos ou sua pluralidade não caracterizaria o sistema financeiro. O predicativo "financeiro" não 
cogita a ideia da diversidade de bancos, mas a interligação com o instituto do dinheiro: meio legal e oficial para a liberação de obrigações pecuniárias (Castro, 2005).

A intervenção do Estado foi pertinente para o direcionamento e limitação da moeda em circulação. Nesse momento, verifica-se o início do que hoje chamamos de Sistema Financeiro, não sendo este apenas um conjunto de instituições, mas "a gradual intromissão normativa na instrumentação prática dos processos circulatórios da produção do dinheiro" (Castro, 2005).

É exatamente a organização estrutural adicionada à legislação (regras do jogo) o que resulta no sistema financeiro. Pode-se afirmar que a moeda e sua circulação tornaram-se assuntos próprios do Estado, geridos por meio de normas, as quais determinam a forma como os agentes devem se comportar em cada segmento econômico. O Estado assumiu, indiscutivelmente, a posição de condutor das regras do jogo econômico, apresentando como aliados o tempo e a legislação para o fortalecimento das instituições.

A interferência regulatória do ente estatal no setor monetário pôde ser aprimorada no decorrer do tempo, sendo eficaz para a ordem econômica buscada pelas sociedades modernas.

\subsection{COMPOSIÇÃO DO SISTEMA FINANCEIRO NACIONAL E ORDEM ECONÔMICA}

A atuação do Estado no âmbito econômico-privado prevista pela Constituição de 1988 é resultado da evolução do ordenamento jurídico pátrio. É possível classificar o atual Estado de neoliberal, uma vez que, ao preocupar-se com fatores sociais, ele afasta-se do modelo constitucional clássico liberal, tornando-se um modelo híbrido ao unir valores públicos e privados.

A nova Constituição mescla premissas de Estado Liberal e do Intervencionismo Estatal, pois, ao passo que assegura a livre iniciativa e a concorrência, regula as ações do mercado, e cria a possibilidade de o Estado ingressar na economia e definir quem poderá, também, atuar nos segmentos econômicos.

Eros Grau (1998) acentua que o princípio da livre iniciativa seria um desdobramento da liberdade, que por sua vez é descrita como "a sensibilidade e a acessibilidade às alternativas de conduta e de resultado".

Luiz Alberto Araújo e Nunes Júnior, referindo-se à livre iniciativa, acrescentam que:

... aplicada à realidade social que pretende ordenar, a regra indica a

liberdade de iniciativa econômica em sentido amplo. Em outras palavras, não se limita à iniciativa privada, mas abrange também a iniciativa cooperativa ou associativa (artigos $5^{\circ}$, XVII e XVIII, e 174, parágrafos $3^{\circ}$ e $4^{\circ}$ ), a iniciativa autogestionária e a iniciativa pública (artigos. 173, 177 e 192, II). ${ }^{9}$ 
O princípio da livre iniciativa, contudo, não é absoluto, pois há previsões de limitações dos critérios e situações nas quais nem todos poderão adentrar nas infinitas organizações econômicas. Previsões negativas na legislação priorizam, mesmo não parecendo à primeira vista, o bem-estar social, ao permitir apenas aos considerados responsáveis e qualificados a exploração de alguns segmentos econômicos.

Têm-se, por conseguinte, as limitações postas à atuação do próprio Estado na economia (artigos 173 e 175 da CF); a existência do monopólio legal (artigos 176 e 177 da CF) e do monopólio natural; além dos casos que necessitam da autorização estatal prévia, dentre eles, destaquem-se as instituições financeiras e assemelhadas. ${ }^{10}$

Com efeito, o parágrafo único do art. 170 da CF prevê a relativização do princípio da livre iniciativa: "é assegurado a todos o livre exercício de qualquer atividade econômica, independentemente de autorização de órgãos públicos, salvo nos casos previstos em lei”. Da mesma forma, apresentam-se as considerações do autor Eros Grau: “... o que mais importa considerar, de toda sorte, é o fato de que, em sua concreção em regras atinentes à liberdade de iniciativa econômica, o princípio, historicamente, desde o Decreto d'Allarde, jamais foi consignado em termos absolutos". 11

A Carta Maior de 1988 separou a Ordem Social da Ordem Econômica e a esta agregou o Sistema Financeiro Nacional (SFN) (Título VII), estruturando-o a fim de promover o desenvolvimento e o equilíbrio do País, prevendo sua regulação por meio de leis complementares.

Há no ordenamento jurídico diversas leis dispondo de forma específica sobre as instituições que estruturam o SFN, sendo a Lei 4.595/64 a que dispõem sobre a constituição do Sistema Financeiro:

Art. $1^{\circ}$ O Sistema Financeiro Nacional, estruturado e regulado pela presente Lei, será constituído:

I - do Conselho Monetário Nacional;

II - do Banco Central do Brasil;

III - do Banco do Brasil S.A;

IV - do Banco Nacional do Desenvolvimento Econômico;

$\mathrm{V}$ - das demais instituições financeiras públicas e privadas.

Pertinente se faz, portanto, tecer algumas considerações sobre cada inciso do artigo supracitado.

O Conselho Monetário Nacional (CMN), órgão colegiado no âmbito do Ministério da Fazenda, é composto, atualmente, do Ministro da Fazenda, do Ministro do Planejamento e Gestão e do Presidente do Banco Central do Brasil.

Como funções precípuas encontram-se a orientação da aplicação dos recursos das instituições financeiras (públicas ou privadas), propiciando condições favoráveis ao 
desenvolvimento harmônico da economia nacional, bem como a coordenação das políticas monetária, orçamentária, creditícia, fiscal e da dívida pública (interna e externa).

O Banco Central do Brasil (Bacen), autarquia federal vinculada ao Ministério da Fazenda, é responsável por conceder ${ }^{12}$ autorizações às instituições financeiras a fim de que possam funcionar no País, instalar ou transferir suas sedes ou dependências, inclusive para o exterior, serem transformadas, fundidas, incorporadas ou encampadas, praticarem operações e terem prorrogados os prazos concedidos para funcionamento, alterarem seus estatutos e alienarem ou, por qualquer outra forma, transferirem o seu controle acionário.

Dentre as alterações trazidas pela Constituição de 1988, pode-se destacar o caráter inegociável, intransferível e sem ônus das autorizações para o funcionamento de novas instituições, e a obrigação de elas preencherem os critérios para ser possível a permissão de funcionar no país na forma da lei do sistema financeiro nacional, quais sejam, os diretores da pessoa jurídica devem ter capacidade técnica, reputação ilibada e comprovar capacidade econômica compatível com o empreendimento.

Por sua vez, o Banco do Brasil (BB) é constituído como sociedade de economia mista vinculada ao Ministério da Fazenda; atualmente, o BB funciona como agente financeiro do Tesouro Nacional, recebendo tributos federais, pagamentos e suprimentos do orçamento da União, de acordo com orientação recebida do Ministério da Fazenda. Além dessas atribuições ele executa a política de preços mínimos de produtos agropecuários e financia atividades predeterminadas como prioritárias pelo governo.

O Banco Nacional do Desenvolvimento Econômico Social (BNDES), uma empresa pública federal vinculada ao Ministério da Fazenda, tem como principal objetivo financiar, em longo prazo, os empreendimentos que contribuam para o desenvolvimento do País.

Quanto às demais instituições financeiras cabe transcrever os artigos 17 e 18 da Lei de Reforma Bancária de 1964:

Art. 17. Consideram-se instituições financeiras, para os efeitos da legislação em vigor, as pessoas jurídicas públicas ou privadas, que tenham como atividade principal ou acessória a coleta, intermediação ou aplicação de recursos financeiros próprios ou de terceiros, em moeda nacional ou estrangeira, e a custódia de valor de propriedade de terceiros.

Parágrafo único. Para os efeitos desta lei e da legislação em vigor, equiparam-se às instituições financeiras as pessoas físicas que exerçam qualquer das atividades referidas neste artigo, de forma permanente ou eventual.

Art. 18. As instituições financeiras somente poderão funcionar no País mediante prévia autorização do Banco Central da República do Brasil ou decreto do Poder Executivo, quando forem estrangeiras. 
O controle e a emissão da moeda oficial no país, como já dito, são ofícios exclusivos do Estado/ União, como ditado pela CF/88 em seu art. 164 e pelos artigos $8^{\circ}$, $9^{\circ}$ e $10^{\circ}$ da lei 4.595 de $31 / 12 / 1964$.

A Lei 4.595/64 atribui ao Banco Central a emissão de moedas oficiais; o Bacen, contudo, é subordinado ao comando do Conselho Monetário Nacional que permite e dita a quantidade do numerário posto em circulação.

No Brasil, a cunhagem ou impressão da moeda oficial é realizada, exclusivamente, pela Casa da Moeda, não sendo, ainda, o momento da emissão e circulação, posto que somente quando o Banco Central do Brasil entrega as cédulas ou moedas metálicas ao banco, perfaz-se a emissão/ circulação.

A exclusividade para a emissão de papel-moeda bem como a legitimidade para a imposição de curso forçado em determinado território são aspectos do poder político. A razão da atenção legislativa e política dada ao meio circulante deve-se ao fato de que ele seja expressão de riqueza e, em consequência, de poder.

Como o dinheiro representa poder, será poderoso, também, quem possa produzi-lo e impor sua utilização dentro de um dado espaço. Por isso, há a preocupação de controlá-lo e distribuí-lo ao público, a fim de evitar a concentração de riqueza para pequena parcela da sociedade e até mesmo um desequilíbrio econômico.

Que o sistema financeiro seja uma forma de intervenção estatal, por meio de normas permite que as relações financeiras, que envolvem circulação de dinheiro, tenham segurança jurídica.

Comprova-se tal afirmação, bem como a amplitude do sistema financeiro, o fato de o dinheiro estar entrelaçado à vida das pessoas, sendo apenas os interessados pela ciência econômica a questionar e entender como se dá a sua existência, emissão e distribuição. A atenção mundial se volta a essas questões, quando surge um fato econômico que impossibilite a devida circulação da moeda a ponto de interferir nas transações econômicas básicas e essenciais da sociedade.

\subsection{FUNÇÕES DO SISTEMA FINANCEIRO NACIONAL}

Instituições e instrumentos financeiros (meio de transferência de recursos dos ofertadores aos tomadores) compõem um conjunto sistemático que, por meio das regras (normas), tornam um sistema financeiro eficiente ao permitir a liquidez dos ativos no mercado.

O Sistema Financeiro Nacional pode ser dividido em subsistemas: o normativo e o operativo. ${ }^{13} \mathrm{O}$ primeiro exerce a função de regular e fiscalizar todo o sistema mediante o poder normativo das autoridades monetárias; o segundo é constituído de atores do mercado financeiro, ${ }^{14}$ as instituições.

A principal consequência, da intermediação realizada pelos agentes do sistema financeiro é o compartilhamento dos riscos, da liquidez e da informação entre os investidores e poupadores (Hillbrecht 1999) e, além disso, entre os tomadores de 
fundo, ou seja, aqueles que não detêm de recursos suficientes para alcançar o consumo desejado.

Logo, a possibilidade de expandir os portfólios através do Sistema Financeiro diversifica os investimentos dos poupadores, diluindo os riscos do negócio. Em vez de investir toda sua reserva econômica em apenas em um determinado mercado, o poupador poderá escolher, dentre variadas opções, os mercados melhores para investir.

Em decorrência da ampliação do leque dos investimentos, há uma redução do risco, pois, caso não haja retorno em investimentos, os bons resultados nos outros poderão compensar as possíveis perdas.

A maior liquidez do sistema resulta na maior facilidade de que um ativo financeiro seja trocado (negociado) por outros ativos, bens ou serviços.

Seguindo a mesma linha, o compartilhamento de informação persegue um problema enfrentado nos mercados, denominado assimetria da informação ou informação assimétrica.

No financiamento direto (quando o poupador e o tomador negociam entre si) concretiza-se um investimento eficiente somente se o investidor souber como sua renda será empregada pelo tomador, para avaliar a possibilidade de retorno do empréstimo. Ao lhe ser negada a informação correta pelo tomador, o investidor poderá decidir de forma ineficiente, realizando um negócio prejudicial para si e para o mercado, existindo, então, a assimetria da informação.

No caso de haver o envolvimento de intermediários financeiros (financiamento indireto), como nas transferências de fundos, o banco cuida de internalizar e compartilhar os riscos de um possível não retorno do capital, por meio de, por exemplo, contratos, critérios exigidos aos possíveis tomadores, juros, e outros.

Portanto, é possível afirmar que a regulamentação do sistema financeiro visa disponibilizar informações essenciais aos investidores, controlar a oferta da moeda, e permitir o melhor funcionamento do próprio sistema financeiro.

A regulação do sistema financeiro tem, no aspecto geral, como fim último, o equilíbrio econômico, cujo objetivo é impedir a probabilidade de crises financeiras. Desta forma, este sistema poder realizas sua principal função, proteger a economia e sociedade.

\subsection{CRIMES CONTRA A ORDEM ECONÔMICA}

O Estado Democrático de Direito, instituído pela Constituição Federal de 1988, resguarda algumas garantias, como a ordem econômica. Isso porque, no mundo capitalista que busca incessantemente o acúmulo de riquezas, constatam-se ações no sentido de alcançar mais facilmente o que de fato importa na atualidade: o dinheiro.

Agir contrário ao previsto no ordenamento normativo, ludibriando as exigências (precauções) estabelecidas pelas autoridades monetárias a fim de facilmente exercer 
ou obter o pretendido, é voltar-se contra o Sistema Financeiro Nacional, o que caracteriza crime por afetar a sociedade com um possível desequilíbrio econômico.

\subsection{BEM JURÍDICO}

O direito penal, por si, protege os bens jurídicos (corpóreos ou incorpóreos) das relações sociais. É, de fato dificultoso, o controle formal como resposta imediata nas ações criminosas no âmbito econômico, pois elas estão inseridas em um universo de possibilidades, sofisticação e inteligência.

Um ramo específico, denominado Direito Penal Econômico, trata das condutas lesivas à ordem econômica e, em consequência, ao Sistema Financeiro Nacional.

Indaga-se: qual seria o bem jurídico tutelado pelo Direito Penal Econômico? Se o Direito Penal Clássico indica as condutas (fatos) proibidas e suas referidas sanções, não existindo crime sem lei anterior que o defina, seguiria a mesma linha a tutela do Direito Penal Econômico?

Segundo Knut Amelung, a sociedade é como um sistema global e o direito um subsistema que interage com os demais sistemas para garantir a sua existência. O direito penal é central para garantir tal sobrevivência porque mantém seu equilíbrio por meio das sanções. Desta forma, prossegue o autor, considera-se "delito" tudo aquilo que impeça o eficiente funcionamento do sistema, e "bem" jurídico, por sua vez, as "funções necessárias para a conservação do sistema social”. 15

Para Winfred Hassemer, o que importa na individualização do bem jurídico é o seu valor subjetivo e seu papel "com as variantes dos contextos sociais nos quais ele aparece”. 16

Para o Direito Penal Econômico a tutela não recai sobre um fato previamente descrito ou previsto, mas na própria ordem econômica e seu equilíbrio. Assim tudo aquilo que tentar produzir lesões na ordem deverá ser (repelido) alvo de sanções.

Acerca dos delitos econômicos, o Código Penal Brasileiro limita-se a prever alguns artigos, ${ }^{17}$ (ao invés de o Direito Penal Econômico ter sido plenamente exposto no atual código ele foi fragmentado em leis especiais). ${ }^{18}$

Pimentel (1973) define o Direito Penal Econômico como "o conjunto de normas que tem por objeto sancionar, com as penas que lhe são próprias, as condutas que, no âmbito das relações econômicas, ofendam ou ponham em perigo bens ou interesses juridicamente relevantes".

A Lei 7.492/86 tem como o bem jurídico tutelado, a proteção do Sistema Financeiro Nacional contra lesivas condutas, exemplificando 22 tipos penais, dentre eles, divulgação de informação falsa; gestão fraudulenta e temerária; apropriação ou desvio de bens móveis; remuneração sobre operação de crédito ou de seguro; instituição financeira não autorizada que efetuar operação de câmbio não autorizada com o fim de promover evasão de divisas do País.

Se a Ordem Econômica e Financeira abrigam-se na Constituição e dela são 
indissociáveis, indubitavelmente, suas regras constitucionais e esparsas buscam uma sociedade livre, justa e solidária.

\section{ECONOMIA SOLIDÁRIA}

Um dos focos da ciência econômica é responder a questionamentos advindos da dificuldade de alocar bens e distribuí-los entre os grupos sociais de maneira eficiente. Isso porque um dos desafios na vida em sociedade é determinar a melhor utilização dos recursos para a produção de bens e serviços essenciais à vida do indivíduo, que, por sua vez, possui desejos e necessidades ilimitadas.

No liberalismo, o próprio mercado regula as questões econômicas, decidindo assuntos sobre o quê, como e para quem deverá ser destinada a produção dos bens. Contrária a essa realidade de economia de mercado, há a chamada economia centralizada, na qual é o Estado que comanda e decide as principais questões econômicas.

Com efeito, as sociedades, em sua maioria, não seguem rigidamente nenhum dos dois tipos de organização econômica (de mercado ou centralizada); o Brasil, por exemplo, segue a economia de mercado, entretanto, a sua autodeterminação é limitada e, nesse limite, encontra-se o Estado, executando o papel de regulador normativo supervisor e protetor da ordem econômica.

\section{I Conceito de Economia Solidária}

A economia solidária, a despeito de ter nascido no interior do capitalismo, contrapõe-se aos valores da economia de mercado e da economia centralizada.

Existe, na literatura, certa dificuldade em conceituar a economia solidária; alguns autores mesclam seu conceito com o da autogestão, do cooperativismo, da economia informal ou economia popular, que são possíveis modos de organizar a economia solidária. É possível citar a definição de economia solidária trazida por Luis Razeto na seguinte perspectiva:

Uma formulação teórica de nível científico elaborada a partir e para dar conta de conjuntos significativos de experiências econômicas (...) que compartilham alguns traços constitutivos e essenciais de solidariedade, mutualismo, cooperação e autogestão comunitária, que definem uma racionalidade especial, diferente de outras racionalidades econômicas. ${ }^{19}$

Em sua maioria, os movimentos instituidores de economia solidária nasceram sob o impulso de uma dinâmica socioeconômica, fruto de crise econômica, ${ }^{20}$ ou seja, as experiências solidárias são perseguidas por quem não encontra no mercado tradicional meios de suprir suas necessidades, e tais experiências têm como protagonistas os excluídos. 
Alguns defendem a hipótese de não haver uma exclusão proposital por parte do mercado e nem mesmo do Estado (ante à falência de suas políticas públicas). A exclusão neste caso seria uma espécie de autoexclusão. Os “excluídos” teriam, portanto, uma visão negativa das instituições financeiras, por acreditarem que os serviços por elas prestados não condizem com sua posição econômico-social.

But passive discrimination may be one explanation: when a financial institution caters to the middle class, it may exclude the poor. Some slum dwellers in Chennai told me they felt uncomfortable entering a bank; they were awed by the better educated and better-dressed bank clerk. ${ }^{21}$

Da passagem transcrita depreende-se um sentimento de que o sistema bancário, com seus custos, não estaria ao alcance daqueles limitados financeiramente. Considere o fato de os indivíduos de classe baixa preferirem tomar empréstimos de pessoas físicas, até mesmo de agiotas, sem mensurar que, nesses casos, os custos tornam-se mais elevados do que se o empréstimo fosse contraído em uma instituição financeira.

Diversas são as formas utilizadas com o fim de praticar a economia solidária. Dentre elas, podemos citar: as empresas autogestionárias, que são geridas pelos próprios trabalhadores no mesmo patamar de igualdade; as finanças solidárias, como um novo mecanismo de aquisição de créditos (tais como cooperativismo de crédito, organizações de microcrédito e microfinanças, fundos solidários, moedas sociais, bancos alternativos, sociedades de garantia); os clubes de trocas, onde as pessoas fazem escambos e utilizam uma moeda social válida apenas naquele local; as redes de colaboração solidária, das quais participam produtores e consumidores dispostos a fomentar a sua comunidade através do consumo local e produção responsável.

\subsection{Economia Solidária no Brasil e no Mundo}

Dificilmente se poderá identificar o surgimento da economia solidária no Brasil, uma vez que sua prática, em diversas ocasiões, é equiparada a terminologias, tais como, terceiro setor, economia social, economia informal, economia popular ou cooperativismo.

Oportuno é tentar, brevemente, relacionar tais termos a uma característica própria possível de diferenciação. O mais comum é confundir economia solidária com economia social; essa última seria a designação dada juridicamente a algumas organizações, tais como, cooperativas, mutualistas, fundações e associações. Quando essas expressões de economia social ganham força política de transformação com visível desenvolvimento econômico, surge a noção de economia solidária. Percebe-se que a economia solidária é uma forma de solidariedade mais atualizada e, porque não dizer, uma economia social regulada.

Identifica-se a economia popular, por sua vez, em um processo social, como, por exemplo, as organizações econômicas populares (OEP). Simplificando, em um dado 
local, espontaneamente, unem-se a necessidade e as habilidades existentes, criando um ambiente econômico com as experiências populares em que, muitas vezes, há o apoio do Poder Público.

Em um plano mais restrito, encontra-se a economia informal, a qual é desenvolvida em uma base individual, não articulada com a sociedade local. São atividades econômicas pessoais informais visando o sustento familiar.

Por fim, o terceiro setor, herdeiro de uma tradição anglo-saxônica, mantém relação estrita com a prática filantrópica, sem fins lucrativos (non-profit organizations).

O certo é que na prática todas essas figuras apresentam características semelhantes, além de estar à margem do Estado e do mercado ou, em alguns casos, relacionarem-se a estes. Dessas práticas não se retira o mérito de serem, também, uma forma de alocação de recurso e distribuição de riqueza.

Tem-se, no governo brasileiro, todavia, vinculada ao Ministério do Trabalho e Emprego (MTE), a Secretaria Nacional de Economia Solidária (Senaes), instituída em junho de 2003, com suas competências estabelecidas pelo Decreto n. 5063, de 8 de maio de 2004; diante disso, o movimento denominado economia solidária é considerado, ainda, uma nova faceta econômica.

Encontra-se, em processo de aprovação, o Projeto de Lei n. 93/2007, o qual visa a criação de um Conselho Nacional de Finanças Populares e Solidárias (Conafis), que será, caso seja aprovado, uma espécie de Conselho Monetário Nacional (CMN) dos Bancos Populares de Desenvolvimento Solidário (BPDS), controlando e regulando as redes de economia solidária e suas ações.

Seria, então, um sistema financeiro transversal direcionado ao segmento de finanças populares e solidárias, em outras palavras, o projeto de lei complementar tem como propósito a não submissão e controle ao e pelo Sistema Financeiro Nacional.

Movimentos tendentes a divulgar, regular, apoiar e instituir formas de economia solidária no Brasil e no mundo são facilmente encontrados, pode-se citar o Instituto Políticas Alternativas para o Cone Sul (Pacs), ${ }^{22}$ a Rede Intercontinental de Promoção da Economia Social e Solidária (Ripess), e a Rede Brasileira de Socioeconomia Solidária (RBSES). No âmbito municipal criou-se na estrutura da Secretaria de Desenvolvimento Econômico (SDE) uma célula de Economia Solidária (Fortaleza, 2009).

Em todo território nacional, cerca de 1.250.000 de pessoas são beneficiadas por iniciativas solidárias, e o Ceará é o segundo Estado com maior número de empreendimentos solidários no Brasil. A quantidade de envolvidos chega a 82.101 pessoas, segundo mapeamento realizado pela Superintendência Regional do Trabalho (Bonfim e Caminha, 2007).

De acordo com o pensamento de Paul Singer (2002), Secretário Nacional de Economia Solidária, esse modelo econômico é uma criação das contradições do capitalismo, "cuja lógica é oposta à do modo de produção dominante". 


\subsection{Moeda Solidária}

Sobre a política adotada pelo sistema monetário, Strohalm (apud Burigo 2001) afirma que ela é baseada no artifício da carência crônica e epidêmica de dinheiro, visando proteger o seu valor dos riscos. Com efeito, a concentração de renda e a restrição do crédito proporcionam a expansão de formas alternativas de organização financeira, de modo que, em algumas práticas de economia solidária, foram criadas moedas sociais.

Antes de adentrar na difícil conceituação e citar as características da moeda social (ou solidária), é oportuno esclarecer que ela se encontra inserida em uma modalidade, e por que não dizer grupo, denominada de moeda paralela, mais especificamente no conceito de paramoeda que pode ser identificada como uma espécie transversal de moeda paralela.

As moedas consideradas paralelas são aquelas que substituem a moeda nacional em algum momento ou situação (até mesmo de forma generalizada, como, por exemplo, as moedas estrangeiras), uma vez que são unidades de cobrança e meios de pagamento diferentes das unidades de cobrança e dos meios de pagamento nacionais (Blanc, 1998). Ainda de acordo com Blanc, a categoria das paramoedas ${ }^{23}$ é utilizada à margem da moeda nacional, portanto, ao invés de concorrer, complementa essa última, pois seu uso é limitado de alguma forma, como nos casos dos clubes de troca onde a utilização é restrita aos associados.

O maior questionamento sobre as referidas moedas paralelas é em quais condições serão emitidas, circularão e serão utilizadas, além da competência daquele (ente, pessoa jurídica) que exercerá tal controle. Independentemente de qual seja a moeda paralela, esta dependerá, de alguma forma ou sob algum aspecto, da moeda nacional e do Estado, no que tange ao estabelecido pela legislação, como trata a afirmação de Carvalho (1992), o que expressa o aspecto de subordinação da moeda paralela à moeda nacional: "Os agentes podem criar substitutos perfeitos para a moeda apenas na extensão em que a autoridade monetária estiver de acordo em garantir a sua retaguarda".

Ao se criar uma moeda local busca-se adaptá-la às circunstâncias e necessidades de um lugar específico, a ponto de ela ter finalidade diversa do pretendido pelo modelo capitalista, ou seja, essa moeda terá uma função social.

Por diversos motivos, grupos sociais optam pela criação de uma moeda local, buscando a sua adaptação às circunstâncias e necessidades do lugar. Com efeito, as políticas neoliberais, a sociedade de mercado e o aumento do desemprego são alguns dos motivos que impulsionam os movimentos para criação de moedas sociais. Em última instância, os grupos decidem criar uma "mola de escape" ao modelo capitalista, instituindo uma economia diversa para aumentar o volume e a circulação da moeda, elevando, assim, o poder de compra em lugares, que, via de regra, estão à margem da economia, e nos quais o dinheiro é uma instituição escassa e com pouca circulação. 
Algumas experiências com moeda alternativa tiveram a inteligência de aplicara teoria da oxidação da moeda, por meio da qual as moedas eram estimuladas a circular sob pena de perder o seu valor com o passar do tempo, uma vez que a redução do seu valor era programada e isso desestimulava seu acúmulo.

A teoria da oxidação foi defendida fortemente pelo economista Silvio Gesell (apud Burigo, 2001); esse autor considerava a poupança um mal para a economia por desestimular a circulação monetária e gerar problemas como a recessão e a concentração de renda.

Adotaremos a definição de Soares a qual afirma que a inclusão social dos economicamente despossuídos não é o único objetivo da moeda social. Ela também visa a estimular valores sociais, evitando o acúmulo de capitais.

A moeda social é uma forma de moeda paralela criada e administrada pelos seus próprios usuários, logo, tem sua emissão na esfera privada da economia.

Ela não tem qualquer vínculo obrigatório com a moeda nacional e sua circulação é baseada na confiança mútua dos usuários, participantes de um grupo circunscrito por adesão voluntária. ${ }^{24}$

Qualquer definição sobre a moeda social não se distancia do aspecto contratual (convenção) encontrado nessa prática, entre os atores envolvidos, com o intuito de utilizar a moeda para atingir o consumo de bens e serviços, impenetráveis naquele determinado local.

Com efeito, a moeda social deverá circular dentro de certos limites, ou seja, entre um grupo limitado de usuários, como meio de circulação de bens e serviços, para o crescimento local, pois essa é uma atividade econômica provedora de bemestar, e seu valor (lastro) será estipulado pela força do trabalho dos indivíduos que compõem o grupo.

Segundo Marusa Freire (2007), ${ }^{25}$ a moeda social cumprirá sua função de complementar a moeda nacional ao "circular em círculos", ou seja, circular em contornos territoriais limitados e em grupos determinados (closed loops). Ela afirma, também, que muitos sistemas de moedas sociais falham nesse sentido, levando essa prática ao insucesso, a ponto de provocar efeitos monetários, necessitando da intervenção do banco central.

A incidência de juros ou intenção de lucros fere a essência da solidariedade proposta pela moeda, uma vez que isso impediria o desenvolvimento de uma economia solidária com lógica capitalista. Espínola Soriano ${ }^{26}$ (2001) ratifica a impossibilidade de juros: "ao afirmarmos que a imposição de juros sobre o circulante é uma posição eminentemente política, com as moedas sociais e as trocas ela é descartada”.

Esse tipo de moeda está à margem da emissão nacional, em outras palavras, é uma emissão privada (descentralizada), não havendo qualquer retaguarda, incluindo 
a estatal, pois a confiança entre os participantes é o que move a economia. É diferente do que ocorre com a emissão de moedas paralelas emitidas pelas instituições financeiras, pertencentes ao Sistema Financeiro e amparadas pelo Estado.

Em todas as análises sobre a emissão e circulação de moedas sociais depara-se com o aspecto legal da prática, que desagua em um impasse, pois a maioria dos países, inclusive o Brasil, não possui qualquer disposição legal proibindo essa prática comunitária com meio de troca próprio.

No Brasil, há leis, inclusive a Constituição Federal de 1988, que determinam o monopólio estatal da moeda corrente, a obrigatoriedade de aceitação da moeda nacional para o pagamento de dívidas, taxas e impostos. Além disso, há leis que prevêem crimes por falsificação da moeda nacional, os quais já foram analisados neste artigo. Outro ponto a ser mencionado é a ausência de tributação sobre essas práticas econômicas.

Algumas declarações de Marusa Freire (2007) sobre moedas sociais merecem crítica, por deixarem transparecer uma fragilidade inaceitável do Banco Central do Brasil em face da existência de moedas sociais no País.

Afirma a Procuradora que "o Banco Central do Brasil está desenvolvendo um projeto para estudar e avaliar os principais aspectos teóricos e práticos relacionados com as experiências de moeda social no mundo", mais adiante declara que "o uso de moedas sociais não é fenômeno novo nos países da Europa e tem sido tolerado pelos bancos centrais sob o argumento de que promove o desenvolvimento das economias locais; apesar de implicar maiores custos e maiores riscos para os detentores da moeda social".

A função do Banco Central do Brasil é ser o guardião da moeda nacional, impedindo que outras surjam. É certo que, como os bancos centrais da Europa, o Bacen também tolera o surgimento de moedas paralelas não reguladas. Essa postura inerte vai de encontro ao que um Banco Central eficiente deveria proporcionar: o fortalecimento da moeda nacional.

\section{O CASO DO CONJUNTO PALMEIRAS}

O Conjunto Palmeiras, um bairro periférico da cidade de Fortaleza, Ceará, foi o primeiro a implementar um novo conceito de economia de maneira organizada. Com o início nos anos 1970, quando moradores de várias regiões da localidade foram desalojados em virtude de um plano de reordenamento urbano, buscou-se, para moradia, uma região afastada, ao sul de Fortaleza. Atualmente a população está estimada em cerca de 30 mil habitantes.

Com o objetivo de articular os moradores e buscar melhorias para o bairro, em 1981 foi criada a Associação dos Moradores do Conjunto Palmeiras (Asmoconp). Inicialmente, a prioridade nas reivindicações da comunidade baseava-se na infraestrutura, visando melhorar nas condições de habitação. Porém, mesmo com os avanços 
obtidos, uma pesquisa realizada pela Asmoconp, em 1997, constatou que noventa por cento das famílias tinham renda familiar abaixo de dois salários mínimos, e que cerca de oitenta por cento da população economicamente ativa (PEA) encontrava-se desempregada (Silva Júnior, 2004).

\section{I Constituição do Banco Palmas}

Diante de tal situação, era necessário buscar alternativas para geração de renda no Conjunto Palmeiras. Assim, a Asmoconp iniciou com um projeto em 1998 ao qual deu o nome de Banco Palmas. Para isso, foi de suma importância o investimento de 2 mil reais os quais foram provenientes, segundo os funcionários do banco, da cooperação técnica alemã GTZ, ${ }^{27}$ que, dentre suas atribuições, contribui financeiramente a fundo perdido para a criação de novos instrumentos financeiros.

Inicialmente, a criação desse projeto comunitário tinha como objetivo fomentar a economia local através de microcrédito para produção e para o consumo local, sem consultas cadastrais, comprovação de renda ou outras restrições impostas pelas instituições convencionais; uma economia baseada somente na confiança e no conceito do cliente perante os demais moradores, uma medida da própria rede de trocas da economia solidária. Para tanto, criaram-se as linhas de microcrédito para incentivar a produção e, com a finalidade de elevar o consumo local, aventava-se a possibilidade de utilização de um cartão de crédito (Palmacard).

Percebe-se que, nesse início, ainda não tinha sido inserida a figura da moeda social; dessa forma os empréstimos e todos os serviços do Banco Palmas realizavam-se com a moeda nacional (real). Diante desse projeto de cunho econômico, a Asmoconp assumiu uma postura híbrida: ao mesmo tempo em que almejava ideais sociais e comunitários, ela procedia por meio de uma lógica essencialmente mercantil.

Silva Junior (2004) salienta que o Banco Palmas passou a não permitir certas liberdades aos moradores, limitando o acesso à moeda apenas àqueles que cumprissem os critérios formulados pela Asmoconp: ficar sócio da entidade eparticipar das últimas reuniões: "No Banco, os desejos a serem atendidos são individuais. O acesso à sala do Banco Palmas é permitido se for para tratar da solicitação de crédito - não na condição de sócio-morador-cidadão, mas como cliente que poderá não ter sua demanda atendida”.

Como dissemos, na economia solidária pode haver uma moeda chamada de social. No Banco Palmas, ela recebeu a denominação palma, isso em 2002.

Entretanto, a introdução da moeda palma no bairro deu-se através da aplicação do Método Fomento, um dos métodos de promoção de desenvolvimento local integrado e sustentável do Movimento Monetário Mosaico (MoMoMo), que realiza uma espécie de "clonagem" de um valor monetário em moeda distinta.

Segundo Silva Junior (2004), na implementação desse método no Conjunto Palmeiras, que é pioneiro no mundo, foi utilizado o valor de R\$51.302 mil, um 
recurso financeiro doado pela Organização Intereclesiástica para a Cooperação ao Desenvolvimento (ICCO), visando a construção de um prédio para a Asmoconp. Essa quantia, conversão em moeda social, resultou em 102.604 unidades monetárias. Os valores em Reais foram destinados à concessão de crédito local e os valores em moeda social destinavam-se à realização de um projeto comunitário, ou seja, para o pagamento da mão de obra ${ }^{28}$ e compra de materiais nos estabelecimentos locais.

A dinâmica seria a seguinte: os empréstimos concedidos em reais aos empreendedores locais deveriam ser devolvidos em moeda local palma, recebida dos trabalhadores do projeto ao qual se destinou o capital inicial. Na realidade, essa medida era para impulsionar a circulação da moeda social, uma vez que "obrigava" os trabalhadores e empreendedores a receberem essa moeda. Em função da "adesão forçada" (cerca de quarenta empreendimentos locais inicialmente), foi possível a aceitação das linhas de créditos em moeda palma e custear parte do pagamento da equipe de gestão da Asmoconp com a moeda do bairro.

Com efeito, para ser possível o crescimento da economia local, com circulação monetária e maior acesso a linhas de crédito, foi necessária a aquisição de mais recursos. Segundo Otaciana Barros, supervisora dos caixas do Banco Palmas, para conseguir recursos públicos, a saída foi criar uma Organização de Sociedade Civil de Interesse Público (OSCIP), denominada Instituto Palmas, uma vez que o Banco Palmas como projeto da Asmoconp encontraria barreiras para a aquisição de recursos junto ao Poder Público. Conclui-se que o Instituto Palmas captaria recursos e o Banco Palmas realizaria os empréstimos.

Nesse sentido, há dois tipos de empréstimos do Banco Palmas, concedidos da seguinte forma: o empréstimo para consumo é destinado a moradores de Palmas, e têm um limite de P\$ 100,00 (cem palmas), sem cobrança de juros; o empréstimo para produção é destinado aos empreendedores cadastrados, com um limite de R\$ $5.000,00{ }^{29}$ Para ter acesso ao crédito, é necessário ser associado ou ter participado das duas últimas reuniões; exige-se o preenchimento de um formulário no qual constam os dados do requerente, o valor e a que se destina o crédito. Com esses dados, um funcionário da Asmoconp verifica a possibilidade da concessão (Saddi, 2004).

Essas práticas comerciais implantadas no bairro, contudo, não foram suficientes para atender todos moradores e, para quebrar o que restava de desconfiança na comunidade, foi criado um cartão de crédito, o Palmacard, com limite de 200,00 palmas, que tem seguinte dinâmica: o consumidor utiliza o cartão em suas compras em locais previamente cadastrados e o pagamento das faturas do Palmacard é feito no Banco Palmas.

Há uma taxa de três por cento cobrada nessas relações de compra e venda através do Palmacard. Otaciana lembra que essa cobrança é para o caso de não pagamento das faturas. Mariana Amori, assessora administrativa do Banco Palmas, revelou que a taxa de três por cento é descontada do valor mensal das faturas dos comerciantes. 
Silva Junior também assegura que essa taxa é cedida pelos comerciantes ao banco em relação às compras realizadas por meio do Palmacard, como taxa de administração.

Jaqueline Dutra, gerente financeira do Banco Palmas, afirmou que a área de abrangência da moeda palma já ultrapassa os limites territoriais do bairro, sendo amplamente aceita, inclusive, em bairros vizinhos. Isso é possível porque os comerciantes oferecem descontos quando o pagamento é realizado em palmas. No transporte alternativo, por exemplo, a passagem custa $\mathrm{R} \$ 1,60$ ou $\mathrm{P} \$ 1,50$ (uma palma e cinquenta centavos). É importante lembrar que o valor da palma é indexado ao real, ou seja, P\$ 1 (uma palma) é igual a R \$ 1 (um real). Os descontos são possíveis pelo fato de não haver nenhuma tributação sobre as operações realizadas com palma ${ }^{30}$ e devido à cooperação dos comerciantes.

\subsection{O Banco Central e a Asmoconp}

Em duas oportunidades, o Banco Central requereu da Asmoconp esclarecimentos sobre as práticas financeiras lá evidenciadas pelo Banco Palmas. A primeira foi em 1998, quando o Banco Central entendeu que o fato do Banco Palmas captar, na época da fiscalização, recursos dos clientes como fundo remuneratório, era um tipo de poupança, uma vez que o banco não tem autorização para desenvolver essa atividade por não ser uma instituição financeira. (Silva Junior, 2004).

Outra intervenção ocorreu em 2003, quando o Bacen acionou o Ministério Público Federal para que o Banco Palmas prestasse esclarecimentos a respeito da emissão da moeda social (a emissão de moeda sem autorização é uma crime contra a União, pois cabe exclusivamente à União a prerrogativa de emitir moeda de curso forçado no país, salvo prévia autorização). ${ }^{31}$

A fiscalização restringiu-se ao depoimento dos diretores do banco na delegacia civil, pois, de posse do parecer da autoridade policial ressaltando o cunho social, o Ministério Público entendeu não ser crime a utilização do Método Fomento.

$\mathrm{Na}$ época dessa investigação, em 2003, o Método Fomento ainda estava em curso. Portanto, difícil era a caracterização de crime contra o Sistema Financeiro, já que, segundo parecer do Banco Central, a moeda nacional permanecia em circulação com o mesmo poder.

\subsection{AnÁlise Jurídica}

Do ponto de vista jurídico, pode-se vislumbrar uma incompatibilidade entre a iniciativa da Associação, ao fomentar a economia local através da criação do Banco Palmas, do Palmacard, e da moeda social, e o ordenamento jurídico brasileiro. O chamado Banco Palma, na realidade, não é uma instituição financeira, não integra o Sistema Financeiro Nacional, e não possui nenhuma autorização jurídica para funcionar como banco. Aliás, por ser um projeto da associação dos moradores (Asmoconp), não há qualquer formalidade no que versa um possível registro em cartório ou junta comercial, bem como na 
Receita Federal, na Secretaria da Fazenda do Estado do Ceará (Sefaz) e na Secretaria de Finanças do Município (Sefin).

Seria inocência ou inteligência criar um empreendimento, funcionando como banco, sem qualquer registro ou fiscalização, em nome do crescimento social?

Independentemente da resposta, o fato é que tal prática não encontra abrigo na legislação; em contrapartida, a emissão de uma moeda solidária por um determinado grupo de indivíduos não está tipificada na Lei 7.492 de 1986 como conduta criminosa.

O direito penal dispõe sobre condutas socialmente relevantes. Isso que dizer que a ciência não antecede os acontecimentos sociais, eles precisam existir e macular de alguma forma a vida em sociedade para serem eleitos como comportamento socialmente relevante. Como dissemos, o direito penal econômico protege a ordem econômica e seu equilíbrio. Apesar de não existir tipificação penal sobre a emissão de moeda solidária, qualquer conduta social que tenha o potencial de exercer o papel exclusivo do Estado de emissão de moedas, gerando males à ordem econômica, deverá sofrer sanções.

A autoridade monetária, além de controlar a emissão da moeda oficial, fiscaliza a possível criação de moedas pelos bancos, como, por exemplo, as moedas escriturais. O cuidado com a quantidade de moeda no mercado busca evitar o seu excesso ou a sua carência. Caso haja um quadro de excesso de moeda (inflação), haverá uma elevação no poder aquisitivo e, em consequência, como os produtos serão insuficientes para a quantidade de moeda em circulação, eles terão seus preços aumentados; caso haja carência da moeda, os preços tendem a diminuir de preço, pois a quantidade de produtos será superior ao volume de moedas em circulação.

O controle do Estado sobre a moeda e demais meios de pagamento é realizada através de política monetária. Se bem gerenciada, a política monetária poderá alcançar os seus objetivos: controle da inflação, equilíbrio da balança de pagamentos, expansão econômica e pleno emprego.

A política monetária tem como desígnio promover a estabilidade do País, para isso é essencial que haja o controle monetário por meio dos instrumentos de redesconto (empréstimo do Banco Central aos bancos comerciais, quando estes apresentam problemas de liquidez); operação de mercado aberto (open market, visando a liquidez monetária, o Governo compra ou vende títulos públicos); e reservas compulsórias (parte dos recursos das instituições financeiras é repassada ao Banco Central).

A Lei 4.595/64, respaldada no art. 164 da Constituição Federal de 1988, atribui ao Banco Central a emissão de moedas oficiais. O Bacen é subordinado ao comando do Conselho Monetário Nacional que irá permitir e ditar a quantidade de numerário em circulação.

O descumprimento, pela iniciativa privada, da previsão de exclusividade do Bacen na emissão de moeda põe em risco a eficácia dos instrumentos de controle da economia empregados pelo Estado. 
Qualquer iniciativa do Estado para tentar diminuir o meio circulante, e assim forçar uma retração do consumo, será ineficiente diante das inúmeras experiências privadas de emissão das moedas sociais, as quais poderão inflar o mercado.

As moedas sociais deverão ser produzidas, distribuídas e controladas pelos próprios usuários, pois elas não têm valor intrínseco, mas, sim, no trabalho dos usuários como lastro.

Ao analisar o caso de Palmas, vê-se uma descaracterização, visto que a palma tem lastro em real, sendo ela dotada de valor intrínseco, desclassificando como moeda social, e atuando em concorrência com o real, pois para cada palma em circulação é necessário que haja um real correspondente sob a custódia do emissor.

Outro fator que comprova a concorrência da palma com a moeda oficial é o exemplo do transporte alternativo se tornar mais barato, uma vez que não há tributação, como dissemos anteriormente. Na lógica econômica, os moradores do bairro são tendenciosos a se tornarem usuários pela conveniência econômica e não pela lógica solidária. Como não há controle, não há tributação e, por isso, a moeda palma concorre com a moeda nacional.

A estrutura criada pela Asmoconp excede o conceito de simples rede de trocas da economia solidária. A moeda palma cumpre a função de unidade de medida, reserva de valor e meio liberatório. Dessa forma, o Banco Palmas, ao emitir essa moeda, está contrariando a política monetária, o poder exclusivo da União de emitir moeda, além de inflar o mercado, uma vez que cabe à autoridade monetária contrair ou expandir o volume da moeda na economia.

No art. 17 da Lei 4.595, de 31 de dezembro de 1964, a definição e competências das instituições financeiras é:

Consideram-se instituições financeiras, para efeitos da legislação em vigor, as pessoas jurídicas públicas ou privadas, que tenham como atividade principal ou acessória a coleta, intermediação ou aplicação de recursos financeiros próprios ou de terceiros, em moeda nacional ou estrangeira, e a custódia de valor de propriedade de terceiros.

O Banco Palmas, na verdade, não é uma instituição financeira, pois não pertence ao Sistema Financeiro Nacional, nasceu de um projeto da Asmoconp, contudo, ele funciona como tal, mesmo sem possuir autorização para funcionar como banco. A intenção de funcionar como uma instituição financeira, sem submeter-se ao controle estatal e legislativo, comprova-se nas seguintes afirmações do Sr. Joaquim Melo, coordenador do Banco Palmas:

Você imagina o que é um banco aberto com a mídia fantástica em cima e a gente completamente liso! Sem nenhum centavo! Era uma coisa, era uma 
barra pesada muito grande: a incerteza se o negócio vai dar certo e se o pessoal vai pagar.

(...)

Então, nós estávamos acostumados com o social, com as lutas sociais. Pra passar disso prum [sic] banco é uma coisa totalmente diferente, porque você muda do social para o econômico. ${ }^{32}$

Nem mesmo as instituições financeiras podem criar e emitir moedas sem autorização, como ocorre no Banco Palmas. Este, além de funcionar como instituição financeira, interfere na política monetária, assumindo o papel do próprio Banco Central.

\section{CONClusÃo}

Os problemas encontrados na prática com moedas sociais poderiam ser superados caso houvesse regulação e fiscalização. Com a propagação dessas experiências monetárias - como ocorreu no Conjunto Palmeiras, onde a moeda social circula e se reproduz sem qualquer controle ou limite - teríamos inúmeros pequenos centros autônomos emissores de moedas distintas em seus valores, formas e regras.

O poder público mantém uma postura omissa em relação a esse tipo de atividade econômica, talvez porque, mesmo caracterizando um ilícito civil, a emissão de moedas sociais eleva o poder de compra dos usuários.

Não se tem qualquer garantia no que tange à eficácia dessa experiência com moeda social. E mais, já se passaram mais de cinco anos após a fiscalização do Banco Central: tal prática, originalmente de cunho social, pode estar, atualmente, funcionando apenas em função de objetivos econômicos e sem autorização.

Não se pode negar que as experiências de economia solidária, inclusive a gerida pela Asmoconp, estão inseridas no sistema capitalista neoliberal, e, portanto, dificilmente elas estariam protegidas dos valores capitalistas. Não são uma forma econômica alternativa que fique a salvo deste sistema econômico.

Como afirmou Marusa Freire (2007), o sistema de moeda social deverá obedecer um curso normal, qual seja: formar um círculo fechado. Dessa forma, caso ultrapasse os limites daquele grupo, a moeda social provocará efeitos monetários. O que dizer em relação a alguns transportes públicos que aceitam a moeda palma? Como o trajeto do transporte público não se limita ao bairro, a moeda social está chegando a lugares e a pessoas não mensuradas.

Pode-se entender que há um desacordo entre a iniciativa da Asmoconp e a legislação constitucional vigente, podendo-se, inclusive, vislumbrar crime contra o Sistema Financeiro Nacional, já que a prerrogativa de emitir moeda é de exclusividade total do Banco Central do Brasil. 
Em outras palavras, o que está ocorrendo no Conjunto Palmeiras usurpa uma das prerrogativas atribuídas, por lei, do Banco Central do Brasil, qual seja a emissão de moedas privadas, ditas solidárias.

Como prova disso, algumas afirmações do Sr. Joaquim Melo, indicadas no capítulo anterior, deixam transparecer que o projeto pretende que o Banco Palmas funcione como um banco comercial com foco meramente mercantil.

Não se pode olvidar a taxa de administração de três por cento, descontada pelo Banco Palmas do valor das compras realizadas pelos consumidores por meio do Palmacard. Sem dúvida, isso não poderia ocorrer em uma economia solidária, de cunho social, onde todos são voluntários.

É necessário que o Poder Público tenha uma posição frente à emissão de moedas sociais, seja para regular ou para proibir, antes mesmo de se tornar uma situação incontrolável, que porá em risco a ordem econômica.

: ARTIGO APROVADO (20/12/2010) : RECEBIDO EM 04/05/2010

NOTAS

* Este artigo é resultado de uma pesquisa que teve apoio da Fundação Cearense de Apoio ao Desenvolvimento Científico e Tecnológico (Funcap).

1 O termo moeda deriva do latim moneta (lugar onde se cunhavam moedas em Roma, no Templo Juno Moneta).

2 O conceito de moeda que norteou nossa pesquisa é o que nos trás Ronald Hillbrecht: "Moeda é tudo aquilo que as pessoas aceitam como pagamento por bens e serviços e como pagamento de dívidas” (1999, p.17).

3 Teoria econômica da Idade Moderna.

4 A Espanha foi um dos países fortemente influenciados pelo metalismo.

5 A expressão "nominalismo" tornou-se conhecida pelo autor Georg Friedrich Knapp (1842-1926) em sua obra Staatliche Theorie des Geldes [Teoria estatal da moeda] publicada em 1905, na Alemanha.

6 Menger apud Soares, 2006, p. 52, 54.

7 Knapp apud Wray, 2003, p. 45.

8 Ao analisar essas teorias verifica-se uma imprecisão sobre o que vem a ser dinheiro e moeda, de modo que os autores utilizaram, em alguns momentos, as nomenclaturas como se fosse a mesma coisa. O importante é esclarecer que moeda é qualquer bem utilizado para viabilizar as trocas (comércio), ao passo que dinheiro é a moeda instituída pelo Estado por força de lei. 
9 Luiz Alberto Araújo e Nunes Júnior, 1999, p. 348.

10 Consideradas as caixas econômicas; bancos comerciais; bancos múltiplos; bancos de desenvolvimento; bancos de investimento; sociedades de crédito, financiamento e investimento; sociedades corretoras de câmbio e de títulos e valores mobiliários; sociedades distribuidoras de títulos e valores mobiliários; sociedade de crédito imobiliário; sociedades de arrendamento mercantil; e cooperativas de crédito, todas dependerão de autorização prévia do Banco Central do Brasil (Instrução Normativa n. 32/91 do DNRC e Leis 4.595/64, 4.728/65 e 5.764/71).

11 Eros Grau, 2005, p. 205.

12 Encontra-se disposto no art. 10 da Lei 4.595/64, a qual instituiu o Conselho Monetário Nacional (CMN), ser competência do Banco Central autorizar o funcionamento das instituições financeiras. “Art. 10. Compete privativamente ao Banco Central da República do Brasil: X - Conceder autorização às instituições financeiras, a fim de que possam: a) Funcionar no País".

13 Segundo a classificação os atuantes do subsistema normativos são: Conselho Monetário Nacional, Banco Central do Brasil, Comissão de Valores Monetários, Banco do Brasil, Banco Nacional do Desenvolvimento Econômico. No caso do subsistema operativo, este é composto de bancos múltiplos; bancos comerciais; caixas econômicas; bancos de investimento; bancos e companhias de desenvolvimento; financeiras; sociedades de créditos imobiliários; bolsas de valores; sociedades corretoras; agentes autônomos de investimentos; companhias de seguros; leasing; factoring e consórcios.

$14 \mathrm{O}$ mercado financeiro pode ser dividido em quatro grupos: Mercado Monetário, Mercado de Crédito, Mercado de Capitais e Mercado Cambial (Hillbrecht,1999, p. 22).

15 Knut Amelung apud Luisi, 1998, p. 104.

16 Winfred Hassemer apud Luisi, 1998, p. 105.

17 São os artigos 172;175;177, bem como os artigos 272, 273, 274 e 279.

18 Lei 11.101/2005; Lei 4.728/1965; Decreto-Lei n. 73; Lei 4.595/1964; Lei 1.521/1951; Lei 4.729/1965, revogada tacitamente pela lei 8.137/1990; Lei 4.591/1964; Lei 7.492/1986; Lei 8.078/1990; Lei 9.279/1996; Lei 8.176/1991; Lei 9.609/1998; Lei 9.613/1998; Lei 10.028/2000.

19 Luis Razeto, 1993 , p. 40.

20 Lévesque, Malo e Girard apud Lechat, 2005.

21 Rajan, 2006, v. 43, n. 1

22 Organização sem fins lucrativos dedicada ao desenvolvimento solidário, com sede no Rio de Janeiro e fundada em 1986.

23 Apenas para melhor compreensão, vales transporte, tickets refeição, milhagens de companhias aéreas, dentre outros, são exemplos de paramoedas.

24 Soares, 2006, p. 135

25 Coordenadora-geral do Centro de Estudos Jurídicos da Procuradoria-Geral do Banco Central.

26 Ruth Espínola Soriano é economista do Pacs, diretora do Instituto de Economistas do Rio de Janeiro e integra a atual coordenação da Rede de Trocas do Rio de Janeiro.

27 Jeová Torres (2004) afirma que o capital inicial para a constituição do Banco foi doação da ONG Cearah Periferia.

28 Apenas vinte por cento do pagamento dos trabalhadores eram feitos em real, o restante era feito em moeda social. Segundo a legislação trabalhista, pelo menos trinta por cento do salário deve ser pago em dinheiro (art. 82 da CLT). 
29 Esse empréstimo é realizado com uma parceria com o Banco Popular e os juros variam de dois a quatro por cento (essa informação foi obtida em entrevista com Mariana Amori, realizada no dia 17/09/2007, na sede da Asmoconp).

30 Não faremos uma análise de natureza tributária das operações efetuadas em Palmas, pois isso foge do escopo deste artigo.

31 Não foi possível ter acesso aos documentos da fiscalização.

32 XXXX apud Silva Junior, 2004, p. 50, 71.

\section{REFERÊNCIAS BIBLIOGRÁFICAS}

AMORI, Mariana. Entrevista realizada em set. 2007, por M. Figueiredo, na Asmoconp, Fortaleza, para a pesquisa Atividade Financeira e Moeda: Análise da experiência do Conjunto Palmeiras.

ANDREZO, Andrea Fernandes; SIQUEIRA LIMA, Iran. Mercado financeiro - Aspectos históricos e conceituais. São Paulo: Fipecapi/USP, 1999.

ARAÚJO, Luiz Alberto David; NUNES JR., Vidal Serrano. Curso de direito constitucional. 2 ed. São Paulo: Saraiva, 1999.

AVELAS NUNES, Antonio. A filosofia social de Adam Smith.Prim@ facie: Revista da Pós-Graduação em Ciências Jurídicas, Universidad de La Rioja, v. 4, n. 6, p. 5-41, 2005. Disponível em: <http://dialnet.unirioja.es/>. Acesso em: 2 jan. 2009.

BARROS, Otaciana. Entrevista realizada em set. 2007, por M. Figueiredo, na Asmoconp, Fortaleza, para a pesquisa: Atividade Financeira e Moeda: Análise da experiência do Conjunto Palmeiras.

BLANC, Jérôme. Las monedas paralelas: evaluación y teorias del fenômeno, 1998. Disponível em:

$<$ http://money.socioeco.org >. Acesso em: 23 ago. 2008.

BONAVIDES, Paulo. Curso de direito constitucional. 9. ed. São Paulo: Malheiros, 2000.

BONFIM, Cristiane; CAMINHA, Suelem. Ceará é o segundo em economia solidária. Diário do Nordeste Online, Fortaleza, 3 mai. 2007. Disponível em: <http://diariodonordeste.globo.com/materia.asp?codigo=429568>. Acesso em: 9 nov. 2008.

BURIGO, Fábio Luiz. Moeda social e a circulação das riquezas na economia solidária. Florianópolis, SC, fev. 2001. Disponível em: <http://www.ifil.org/rcs/biblioteca/burigo.htm>. Acesso em: 21 nov. 2008.

CAMARGO, Sabino Lamego de. Fundamentalidade. Disponível em:

http: / / www.scamargo.adv.br/scripts/forum/frMensagemAntigo.asp?Tema=Moeda+ -

+ Valor + Nominal $+\mathrm{e}+\mathrm{M} \%$ EDnimo + Existencial $\&$ IDTOPICO $=40 \& \mathrm{msg}=$ Fundamentalidade $\& \mathrm{ID}=71$.

CAMINHA, Uinie, Correspondentes bancários no direito brasileiro: Conceito e Disciplina. Revista de Direito Mercantil. São Paulo, SP, n. 137, 2005.

CANOTILHO, José Joaquim Gomes. Direito constitucional. 3. ed. Coimbra: Almedina, 1999.

CARVALHO, Fernando. J. C. Moeda, produção e acumulação. In: SILVA, M. Luiza F. (Org.) Moeda e produção: teorias comparadas. Brasília: Edunb, 1992.

CASTRO, Raphael Vally de. A dimensão jurídica dos instrumentos monetários e seus reflexos no sistema financeiro. Dissertação (Mestrado em Direito) - Faculdade de Direito, Universidade de São Paulo, São Paulo, 2005

DE CHIARA, José Tadeu. Moeda e ordem jurídica. Tese de Doutoramento. Faculdade de Direito na Universidade de São Paulo, São Paulo, 1986.

DI RUFFIA, Paulo Biscaretti. Direito constitucional: instituições de direito público. Tradução de Maria Helena Diniz. São Paulo: Ed. Revista dos Tribunais, 1984.

DUTRA, Jaqueline: Depoimento feito em jul. 2006, obtido por F. Matos, na Asmoconp, Fortaleza, para a pesquisa: Atividade Financeira e Moeda: observações iniciais sobre a experiência do Conjunto Palmeiras. FERREIRA FILHO, Manuel Gonçalves. Curso de direito constitucional. 25. ed. São Paulo: Ed. Saraiva, 1999. FORTALEZA discutirá criação de lei específica para Economia Popular e Solidária. Adital, Fortaleza, 9 mai. 2009. Disponível em: <http://www.adital.com.br/site/noticia.asp?lang=PT\&cod=38602>. Acesso em: 13 mai. 2009 . 
FREIRE, Marusa. MOEDAS SOCIAIS: O que são, como funcionam e por que podem ser consideradas instrumentos de desenvolvimento local. VI SEMINÁRIO NACIONAL DE MICROFINANÇAS. Porto Alegre, 15 jun. 2007. Disponível em: <http://www.bcb.gov.br/pre/microFinancas/arquivos/horario_arquivos/ apres_62.pdf>. Acesso em: 3 jul. 2008.

Moeda Social: Potencialidades. Caderno Opinião. Correio Braziliense, 26 fev. 2007

GERMER, Claus M. O conceito de "padrão-ouro" e os equívocos da economia política. III ENCONTRO NACIONAL DE ECONOMIA POLÍTICA, NITERÓI-RJ, 1998. Disponível em:

<http://www.iwgvt.org/files/9-germer.rtf>. Acesso em: 30 abr. 2009.

GARCIA JUNIOR, Armando Alvares. Contratos indexados no direito brasileiro e variação cambial. São Paulo: Aduaneiras, 2000.

GRAU, Eros Roberto. A Ordem Econômica na Constituição de 1988. 4. ed. São Paulo: Malheiros, 1998. . A ordem econômica na Constituição de 1988. 10. ed. São Paulo: Malheiros, 2005.

HILLBRECHT, Ronald. Economia monetária. São Paulo: Ed. Atlas, 1999.

JANSEN, Letácio. Texto do Sabino sobre valor nominal. Disponível em:

<http://www.scamargo.adv.br/scripts/

forum $/$ frMensagemAntigo. asp?Tema $=$ Moeda $+\% 2 \mathrm{D}+$ Valor + Nominal $+\mathrm{e}+\mathrm{M} \%$ EDnimo + Existencial\&msg $=$ Fundamentalidade\&IdTopico $=40 \& i d=70>$. Acesso em: 15 mar. 2008.

LECHAT, Noëlle Marie Paule. As raízes históricas da economia solidária e seu aparecimento no Brasil.

Leituras cotidianas n. 152, 16 mar. 2005. Disponível em:

$<$ http://br.geocities.com/mcrost07/20050316a_as_raizes_

historicas_da_economia_solidaria_e_seu_aparecimento_no_brasil.htm>.Acesso em: 3 jul. 2008.

LUISI Luiz. Bens constitucionais e criminalização. Revista CEJ, v. 2, n. 4, jan./abr. 1998.

MARINHO, Henrique. Economia monetária: Teorias e a experiência brasileira. Rio de Janeiro: Ciência Moderna, 2007. PIMENTEL, Manoel Pedro. Direito penal econômico. São Paulo: RT, 1973.

RAJAN, Raghuram. Separate and Unequal. Disponível em:

<http://www.imf.org/external/pubs/ft/fandd/2006/03/straight.htm>. Acesso em: 13 mar. 2009.

RATTI, Bruno. Comércio internacional e câmbio. 11. ed. São Paulo: Lex Editora, 2006.

RAZETO, L. Economia de Solidariedade e organização popular. In: GADOTTI, M. e GUTIERREZ F. (Orgs.)

Educação comunitária e economia popular. São Paulo: Cortez, 1993, p. 34-58.

SADDI, Jairo S. O poder e o cofre: repensando o Banco Central. São Paulo: Textonovo, 1997.

SILVA JÚNIOR, Jeová Torres. Gestão, fato associativo \& economia solidária: a experiência da

Asmoconp/Banco Palmas. 2004. Dissertação (Mestrado em Administração). Escola de Administração,

Universidade Federal da Bahia, Salvador, 2004.

SINGER, Paul. Introdução à economia solidária. São Paulo: Fundação Perseu Abramo, 2002.

SOARES, Cláudia Lúcia Bisaggio. Moeda social: uma análise interdisciplinar de suas potencialidades no Brasil contemporâneo. 2006. Tese (Doutorado em Ciências Humanas). Centro de Filosofia e Ciências Humanas,

Universidade Federal de Santa Cataria, Florianópolis, 2006.

SORIANO, Ruth Espíndola. Rede de trocas solidárias e a socioeconomia solidária. Disponível em:

<http://www.pacs.org.br/artigospublicacao/rededetrocas\%20port.rtf>. Acesso em: 17 nov. 2007.

STANFORD, Jon D. Moeda, bancos e atividade econômica. São Paulo: Atlas, 1976.

WRAY, L. Randall. Trabalho e moeda hoje. Rio de Janeiro: EDUFRJ/Contraponto, 2003.

VERÇOSA, Haroldo Malheiros Duclerc. Bancos centrais no direito comparado: o Sistema Financeiro Nacional e o Banco Central do Brasil (O regime vigente e as propostas de reformulação). São Paulo: Malheiros, 2004.

\section{Uinie Caminha}

Av. Washington Soares, 1321

Edson Queiroz - 60811-905

Fortaleza - CE - Brasil

ucaminhalaunifor.br
Doutora em direito Pela Universidade de São Paulo (USP)

Professora AduUnta da Universidade de Fortaleza (Unifor) E dA Universidade FEDERAL do CeARÁ (UFC) 
Monique Figueiredo

Av. Washington Soares, 1321 Edson Queiroz - 60811-905 Fortaleza - CE - Brasil monique_shalahotmail.com

Graduada em DiReito PELA Universidade dE ForTalezA

Bolsista da Fundação Cearense de Apolo aO Desenvolvimento Científico e TeCnológico - FUnCAP 
